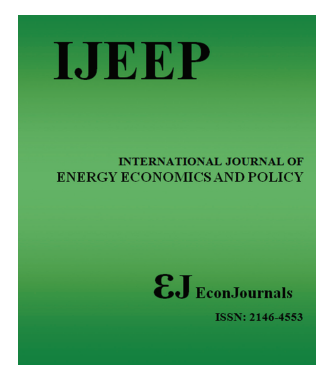

International Journal of Energy Economics and
Policy

ISSN: $2146-4553$

available at http: www.econjournals.com

International Journal of Energy Economics and Policy, 2019, 9(4), 369-380.

\title{
Oil Exploration and Exploitation in Nigeria and the Challenge of Sustainable Development: An Assessment of the Niger Delta
}

\author{
Michael Oguwuike Enyoghasim ${ }^{1 *}$, Lasbrey Anochiwa', F. Tobechi Agbanike1, Iyke Uwazie Uwazie ${ }^{2}$, \\ E. Uma Kalu', O. Kelvin Onwuka1, Sunday Amalunweze Okwor ${ }^{1}$, Ikwor Okoroafor Ogbonnaya ${ }^{1}$ \\ ${ }^{1}$ Department of Economics and Development Studies, Alex Ekwueme Federal University, Ndufu-Alike Ikwo, Ebonyi, Nigeria, \\ ${ }^{2}$ Department of Economics, Michael Okpara University of Agriculture, Umudike, Nigeria.*Email: mic_martserve@yahoo.com
}

Received: 11 January 2019

Accepted: 17 May 2019

DOI: https://doi.org/10.32479/ijeep.7812

\begin{abstract}
The study seeks to evaluate the environmental problems associated with oil exploration and exploitation in the Niger Delta area of Nigeria on one part with a focus on empirical examination of one of the variables highlighted in the literature - emission of $\mathrm{CO}_{2}$ on people's health. With data 1980-2015 drawn from Central Bank of Nigeria bulletin, we employed ordinary least square and three-stage-least square regression model to analyze. Life expectancy at birth is the dependent variable, while carbon emission, gross domestic product per capital, female education, and public health expenditure are explanatory variables. Findings show that carbon emission has a negative coefficient which is in line with the theoretical expectation. It is observable that an increase in carbon emission by one unit will reduce life expectancy by $0.04 \%$. This result supports the unsustainability of the business and gas emissions and oil spill in the delta region as harmful to the wellbeing of the masses.
\end{abstract}

Keywords: Carbon Emission, Oil Exploration, Environmental Degradation, Resource Curse

JEL Classifications: O13, Q33, Q34

\section{INTRODUCTION}

With population of over 170 million people, Nigeria no doubt is Africa's most populous black nation (Aminu, 1997). Again, Nigeria is ranked the highest producer of oil in Africa. Such ranking could have made sense today but for the resource curse phenomenon as advanced by pioneering works of Mahdavy (1970), Karl (1997), Auty (1997); Collier and Hoeffler (1998), Ross (2012), Morrison (2007); Cuaresma et al. (2011); and McGuirk (2013). It is simply "the damaging effects of a country's natural resource wealth on its economic, social, or political well-being" (Sachs and Warner, 2001). Oil exploration and exploitation is the driving force of Nigeria's economy with its attendant defects, one of which is the destruction of ecosystem (Bakare and Fawehinmi 2010). Nigeria desires a growth pattern that is aligned with sustainable ecological development. The problem of environmental degradation due to expansion of oil production activities, the depletion of ozone layer, the emission of $\mathrm{CO}_{2}$ and other poisonous gas substances on people's health is the most challenging problem of the world today (Gul'nar et al., 2019, Anyalechi et al., 2019, Bassey 2001 and Bekturganova, et al. 2019). The question is to what extent can Nigeria talk of sustainable development in the face of avowed contradictions of oil operations in Niger Delta.

Sustainable Development according to (Marop et al., 2015; UNESCO, 2015; Dernback, 2002; Ugoh, 2008) is defined as "the development that meets the needs of the present without compromising the ability of the future generations to meet their own needs." Sustainable national Development is a process of improving the range of opportunities that will enable individual humans and communities to achieve their aspirations and full their potential in a manner that sustains natural resources and the environment of the future generation (Abubakar 2013). An economy functions in the ecosystem. The ecosystem provides the 
factors of production that fuels economic growth: Land, natural resources, labor, and capital (which are created by labor and natural resources). Unfortunately, the manner of extraction and depletion of natural resources, as well as pollution and permanent changes made to the landscape in Niger Delta, has caused harm to the environment deferring sustainability (Nwilo and Badejo (2008); Olaolou, (2008)). Regrettably, many of the costs of the harm created by these economic activities are not borne by those who cause it (as they are shielded by government) but by other people who neither obtain the benefits from the economic activity nor agree to pay the costs related to it (Al Mamun et al., 2014, Ozturk and Acaravci, 2013)., This is what we call negative externality. Therefore any economic activity that destroys the future in the present is not sustainable and should be discarded. Unsustainable patterns of economic production and consumption contribute to global warming, environmental degradation and an upsurge in natural disasters. This in a nutshell is the scenario in Niger delta of Nigeria Onuoha (2007).

The Niger Delta region covers about $75,000 \mathrm{~km}^{2}$ and is home to about 30 million indigenous residents scattered among 40 different ethnic groups, speaking diverse languages and dialects. In 1956, Shell British Petroleum (now Royal Dutch Shell) discovered crude oil at a village Oloibiri in Bayelsa state located within the Niger Delta of Nigeria (Onuoha, 2008; Anifowose, 2008) and commercial production began in 1958. Oil exploration and exploitation has been on-going for several decades in the Niger Delta. It has had disastrous impacts on the environment in the region and has adversely affected people inhabiting that region. Studies have shown that the quantity of oil spilled over 50 years was at least 9-13 million barrels, which is equivalent to 50 Exxon Valdez spills (Kadafa, 2012). The ecosystem of Niger Delta has suffered from decades of oil exploration due to neglect by federal government to legislate and enforce the management of negative economic externalities. If it is not flaring of gas (emission of $\mathrm{CO}_{2}$ ) its oil pollution, contamination of drinking water, deforestation etc. (Kadafa, 2012). Apart from the ecosystem that is devastated, the political economy of the country is also affected due to "rent seeking" and "dutch disease."

While we appal the part of dishonour Nigeria has played in neglecting to learn lessons from mistakes of other mineral dependent countries, it will be equally revealing to look inwards to see the neglect of Oil companies operating in the country. Most of the companies do not operate within the frame of acceptable global practices because of the rent seeking (changing the rules arbitrarily for pecuniary reasons) nature of the economy and 'resources curse' phenomenon. Policies that will define acceptable standard are thrown overboard at the expense of the environment (Lasbrey et al., 2018, Crowson, 1996). At a time the whole world is advocating for sustainable economic growth Nigeria has left its mineral exploration and exploitation at the mercy of 'Hawks'. Many third world countries that are rich in minerals has fallen prey to this phenomenon - Angola, Nigeria, Sudan, Congo, Gabon, Venezuela, Iraq, Iran, Kuwait, Zambia, and Chad etc. Patrick (2004). Though there could be differences from one country to another but the fact is that countries that solely depend on the proceeds of petrodollar put themselves to a great disadvantage. Therefore, while it is easier to join in the debate for sustainable development it appears it will be a mirage to be realised in Nigeria considering the level of distortions.

\section{ECONOMIC DISTORTIONS THROUGH RENT SEEKING AND DUTCH DISEASE}

Before we venture into the obvious as our literature and findings will show it is equally important to bring to fore other distortions and damaging effects associated with oil exploration and exploitation. The issue of "Dutch disease" "rent seeking" and "resource curse." Wright (1990), David and Wright (1997) and Clay and Wright (2005) in different papers have argued "whether resource abundance reflected geological endowment or greater exploitation of geological potential," and came to the conclusion that resource abundance leads not only to greater exploitation but also greater inequality among the people.

In developing countries like Nigeria, abundance of oil has precipitated the "rent seeking" phenomenon. The term "rentseeking" was introduced by Tullock (1967) and was developed and expanded by Kreuger (1974). It is associated with social welfare losses due to corruptive tendencies of institutions. Political institutions conducive to rent-seeking underlie failures of societies to realize benefits from natural resource wealth. Consequently, it could be rightly said that natural resources is a "curse" rather than benefit to the society (Congleton et al., 2008). Again, with respect to conflicts over distribution of resources, Auty's (2001a; 2001b) argues that rent seeking degenerates into corruption which discourages and stifles investment and limits economic growth. The opportunity cost of rent-seeking is forgone entrepreneurship.

The greater the resources endowments, the higher the demand for non-tradable goods, and the smaller will be the allocation of labour and capital to the manufacturing and agriculture sector (Sachs and Warner, 1995). The argument for Dutch disease is defined by this analysis that when an economy experiences a re-source boom (either a terms-of-trade improvement or a resource discovery), the manufacturing sector tends to shrink and the non-traded goods sector tends to expand. The shrinkage of the manufacturing sector is dubbed the "disease," though there is nothing harmful about the decline in manufacturing if neoclassical, competitive conditions prevail in the economy (Sachs and Warner, 1995b; Sachs and Andrew 1997b).

Therefore, this study seeks to evaluate the environmental problems associated with oil exploration and exploitation in Niger Delta, Nigeria on one part and take an empirical examination of one of the variables highlighted in the literature - emission of $\mathrm{CO}_{2}$ on people's health. The findings will support or oppose what we find in the literature that suggests that oil exploration is not entirely beneficial to the Niger Delta region because of attendant damage to the ecosystem. The remaining part of this paper is structured as follows; the literature review, methodology, Discussion, and conclusion. 


\section{LITERATURE REVIEW}

\subsection{Gas Flaring and Effects}

Before the advent of oil prospecting and production in the Niger Delta Region, the people of Niger Delta were farmers as other regions of the country. Specifically, they were fish farmers and the environment was conducive, friendly and viable. The soil was equally fertile and therefore good for farming. Thus, farm produce/yield was high and adequate for the subsistence and commercial needs of the people. Until oil was discovered and production began that altered the environment. One of the major problems associated with oil production is the destruction of the people's livelihood which is the soil and farmlands through gas flaring and oil spillage. In the process of oil production, Nigeria flares about 24 billion cubic meters or 0.84 trillion cubic feet of associated natural gas every year. According to a November report by the Department of Petroleum Resources, $>70 \%$ of the oil fields in Nigeria still flare gas (Ugwaren, 2008). Specifically, Nigeria produces about 2.524 trillion SCF of gas annually and the estimated gas they utilize is put at $2.235 \mathrm{trn}$, with a hefty 289.6 bn SCF flared (Ajugwo, 2013). Oil companies operating in the country find it cheaper to flare gas than to conserve. Though it is illegal to do so, nevertheless corruption and dumbness has made the authorities not to care about the adverse environmental health hazards associated with it (Okonkwo et al., 2015; Uzoma and Mgbemena, 2015).

Gas flaring affects not only the soil but also vegetation, agriculture and crop production (Mathew et al., 2018; Alakpodia, 1989; 2000; Dosunmu and Amadi, 1996; Gogoi and Baruoh, 2002; Ogidiolu, 2003; Efe, 2003). The agricultural soils as well as fresh water and aquatic life have been destroyed by various forms of oil-generated environmental pollution. Farming has become very difficult and even drinking water has become scarce. Flaring activity affects agricultural production of the region. This stunts crops growth and impacts negatively on the yield of their crops - cassava, yam, plantain among others (Olisemauche and Avwerosuoghene (2015). Few examples in the literature will help us understand the effects of gas flaring in some communities in Niger Delta.

Gas flares generate tremendous heat, which makes plant growth difficult, and the ecosystem and aesthetics of the environment destroyed during the laying of the pipelines. Again, gas flaring causes vegetal re-growth problem, depression in flowering and fruiting in these crops and generally diminishes the value of agricultural productivity (Omuta, 1985; Isichei and Stanford, 1996; Alakpodia 2000; Ejuwa 2005).

Obioma (1985) investigated agricultural production decline in the Ogba-Egbema area of Rivers state and found that gas flares and the warmth it generates attract insects in great numbers from the forest at night that causes destruction of the crops in the area. Ukegbu and Okeke (1987) examined the effect of gas flare on the growth, productivity and yield of selected farm crops in Izombe flow station located in Izombe Ohagi/Egbema/Oguta Local Government Area of Imo state. Their findings show about $100 \%$ loss in yield in all the crops cultivated about $200 \mathrm{~m}$ away, $45 \%$ loss for those about $600 \mathrm{~m}$ and $10 \%$ loss in yield for crops about $1000 \mathrm{~m}$ away from the flare. The effects were reduced with increasing distances from the flare.

In a related study Dosunmu and Amadi (1996) investigated the effects of gas flares on the environment and observed a depression in the growing, flowering and fruiting of maize planted in the flare direction. The study also reveals substantial reduction in the yield of soyabeans with decreasing distances to the flare site. Gogoi and Baruoh (2002) studied the effects of natural gas flare on growth, flowering and yield of rice (Oryza sativa L.) near an oil installation of ONGC. The inhibitory effect of flare on crop growth, flowering and yield in rice was observed up to $45 \mathrm{~m}$ distance from the gas flare point. They noted also that intensity of damage was more pronounced up to $30 \mathrm{~m}$ distance, particularly on yield attributing parameters - grain panicle, filled grain, high density grain and grain yield.

Matthew et al. (2018b) employed the auto-regressive distribution lag for the period 1985-2016 to examine the effect of greenhouse gas (GHG) emissions on health outcomes in Nigeria. The results of their study showed that an increase in GHG emissions by $1 \%$ reduces life expectancy by $0.04 \%$ and thus bringing mortality rate to $146.6 \%$. The study's major shortcoming is that it focused only on health outcomes of the people which was captured by life expectancy in relation to $\mathrm{GHG}$ emissions.

Nugraha and Osman (2019) investigated causal relationship between $\mathrm{CO}_{2}$ emissions, energy consumption, value added of three development sectors and household final consumption expenditure in Indonesia using annual data from 1975 to 2014. They applied ADF and PP unit root tests, Johansen co-integration test, and Granger causality test based on vector error correction modelling. $\mathrm{CO}_{2}$ emissions, energy consumption, the value added of industry sector and household final consumption expenditure have a significant effect on the added value of agriculture sector and service sector, while the added value of agriculture sector is a key factor that driven increases the added value of service sector. The results also indicate that although $\mathrm{CO}_{2}$ emission and energy consumption have a mutual effect, increase $\mathrm{CO}_{2}$ emissions tend to give greater effect on energy consumption.

Osabohien et al. (2019) examined how the effect of GHG emissions on crop production in the West Africa sub-region. Social protection was used as a mitigating factor to absorb the effect of GHG emissions. The study engaged a panel data consisting of 14 Economic Community of West African States member countries to analyze the data which was sourced from the World Development Indicators and Country Policy and Institutional Assessments for the period 2000-2016, with the use of fixed and random effects econometric model. Results showed that an increase in greenhouse gas emissions reduced crop production by $0.13 \%$, this is through the lowering of crop yields resulting from the emissions of GHG.

Manasseh et al. (2019) used a different approach to study the well-being of the people. Using annual time series data which covers the period 1981-2014 and multiple regression techniques, investigated the impact of oil price fluctuation and oil revenue on well-being in Nigeria. The variables include oil price fluctuation, 
nominal exchange rate, lag period of inflation and growth rate of consumer index. The findings suggest that oil price fluctuations have no significant impact on well-being, while oil revenue is observed to have a significant and positive impact on well-being. Notwithstanding the insignificant impact of oil price fluctuation, further investigation using Johanson co-integration test shows the existence of long run relationship in the series.

\subsection{Oil Spillages and Effects}

Oil spills cannot be totally avoided in oil drilling operations but the challenge in the case of Niger Delta is the magnitude of the spills and its regular occurrence, with little effort to control it at the appropriate time. When oil spills and not recovered will have an impact on the local environment, spreading over a wide area and affecting both terrestrial and marine resources. What suffers most is the survival of species in the aquatic habitat and also farm lands (Akpan, 2012; Plessl et al. 2017). Causes of oil spillage include corrosion of piping and installations, improper maintenances of infrastructures, the release of crude oils from offshore platforms, sabotage engineering drills, inability to effectively control oil wells, failure of machines and inadequate care in loading and unloading oil vessels (Nwilo and Badejo, 2001, Adati 2012; NNPC 2013).

Akpokodje and Salau (2015) examined oil pollution and agricultural productivity in the Niger Delta of Nigeria and applied Ramon Lopez's Cobb Douglas production function model. Their findings show that increasing levels of oil spill and forest loss negatively affect agricultural productivity, while land, labour and capital positively improved agricultural productivity in the Niger Delta.

Atubi et al. (2015) examining the effects of environmental degradation on human health in nine selected oil communities in Delta State, Nigeria using cluster and principal component analysis, employed both primary and secondary data; 1-year hospital data was used based on data availability and consistency on the required ailments such as bronchitis, cough, asthma, cardiovascular diseases, eye infection and skin infection in order to ascertain the effect of gas flaring on human health. The frequency of occurrences was high indicating statistical significance.

Osuagwu and Olaifa (2018). This study examines the effect of oil spills on fish production in the Niger Delta of Nigeria from 1981 to 2015 using an estimable model based on a Cobb Douglas production function. The variables included in the model are captured fish production, number of fishers, and loan to fishery, oil spills and oil production. The findings suggest that oil spill and oil production negatively affects fish production, while farm labour has a positive effect on fish production.

From the foregoing it is pertinent to do an empirical test on the impact of oil explorations and the attendant emissions on the welfare of the people. These variables ascertain the congruency of the distortions if any and the damages to the environment and people's welfare in the exploitation of oil mineral in Niger Delta in particular and Nigeria in general. Our choice is hydrocarbon emission $\left(\mathrm{CO}_{2}\right)$. Carbon dioxide emissions are those stemming from the burning of fossil fuels and the manufacture of cement.
They include carbon dioxide produced during consumption of solid, liquid, and gas fuels and gas flaring.

\section{METHODOLOGY}

Method of Data Analysis and Source of Data: Simultaneous equation model is best used when there is evidence of simultaneity among variables. This will help to check which one causes the other. Due to this, ordinary least square regression becomes insufficient and we therefore resort to the use of three-stage-least square (SLS) regression. The 2-SLS regression will give a result that is reliable for policy makers to fall back on. This is so as it will help to identify quickly if economic growth causes health or if health causes economic growth and whether policy makers should adopt policies to improve health or to promote economic growth. However in this paper we are only concerned with $\mathrm{CO}_{2}$ gas emission while the aspect that pertains with economic growth is not part of our study. The data for this study is obtained from secondary sources, particularly from Central Bank of Nigeria (CBN) publications such as the CBN Statistical Bulletin, CBN Economic and Financial Review Bulletin (2015) and data from World Bank economic indicator 2016.

The adopted empirical studies model is formulated using the Solow growth theory which states that labour and capital affect economic output. The adopted econometric model is expressed as: $Y=F(H)$

Thus, mathematically stated as:

$$
\mathrm{Y}=\mathrm{a}_{0}+\mathrm{a}_{1} \mathrm{H}+\mathrm{u}
$$

Where $\mathrm{Y}$ is health outcome, $\mathrm{F}$ is functional notation, $\mathrm{a}_{0}=$ intercept or constant; $\mathrm{a}_{1}=$ parameters or co-efficient of explanatory variables; and $\mathrm{u}=$ error term, $\mathrm{H}$ stands for health inputs. In line with economic theory, we added health expenditure, emission $\mathrm{CO}_{2}$, health policy and education into the health production function to determine their impact on life expectancy at birth.

Model I: Impact of emission $\mathrm{CO}_{2}$ on health outcome (life expectancy at birth)

$$
\text { leb }=\mathrm{f}\left(\mathrm{CO}_{2}, \text { femedu, gdppc, ghe }\right)
$$

The Mathematical form of the model:

$$
\mathrm{leb}_{\mathrm{t}}=\alpha_{0}+\alpha_{1} \mathrm{co}_{2} \mathrm{em}_{\mathrm{t}}+\alpha_{2} \mathrm{gdppc}_{\mathrm{t}}+\alpha_{3} \mathrm{ghe}_{\mathrm{t}}+\alpha_{4}
$$

Econometrically:

$\mathrm{leb}_{\mathrm{t}}=\alpha_{0}+\alpha_{1} \mathrm{co}_{2} \mathrm{em}_{\mathrm{t}}+\alpha_{2} \mathrm{gdppe}_{\mathrm{t}}+\alpha_{3} \operatorname{logfemedu} \mathrm{t}_{\mathrm{t}}+\alpha_{4} \mathrm{ghe}_{\mathrm{t}}+\mathrm{v}_{1 \mathrm{t}}$

To take care of possibility of multi-colinearity, we take the log transformation of the variables. Thus:

$\log l$ eb $\mathrm{t}_{\mathrm{t}}=\alpha_{0}+\alpha_{1} \operatorname{logc\mathrm {O}_{2}} \mathrm{em}_{\mathrm{t}}+\alpha_{2} \operatorname{loggdppe} \mathrm{t}_{\mathrm{t}}+\alpha_{3} \operatorname{logfemedu_{\mathrm {t}}+}$ $\alpha_{4} \operatorname{logghe}_{\mathrm{t}}+\mathrm{v}_{1 \mathrm{t}}$

Where: $\log l e b_{t}=\log$ of life expectancy at birth, $\operatorname{logghe}_{t}=\log$ of government health expenditure, $\operatorname{logfemed} u_{t}=\log$ of female 
education (FEMEDU), $\log \operatorname{dpp}_{t}=\log$ of gross domestic product per-capita, $\log \operatorname{co}_{2} \mathrm{em}_{\mathrm{t}}=\log$ of carbon-dioxide emission, $\alpha_{0}=$ constant $, \alpha_{1}, \alpha_{2}, \alpha_{3}$ and $\alpha_{4}=$ structural parameters, $\mathrm{v}_{1 \mathrm{t}}=$ noise that takes care of other variable that could affect health that are not in the model.

\subsection{Description of Variables and Sources of Data}

Life expectancy at birth (LEB): Is life LEB which covers the period of 1980-2015. It was used to proxy health outcome. It indicates the number of years a new born infant would live if prevailing patterns of mortality at the time of its birth were to stay the same throughout its life. The data is gotten from World Bank economic indicators 2016 (Appendix 1).

Gross domestic product per capita (GDPPC): It is gross domestic product divided by midyear population. Data are gotten from World Bank economic indicator 2016.

Government health expenditure (GHE): Is public health expenditure. It is used to proxy health expenditure. It is the sum of current and capital GHE, and covers the period of 1980-2015. Theoretically, an increase in total health expenditure is expected to increase health outcome, thus a positive relationship between the two. The data are gotten from Central Bank of Nigeria Statistical Bulletin (2015).

FEMEDU: Is female primary education over 1980-2015, used as a proxy for education level. Data are gotten from World Bank economic indicator 2016.

Carbon-dioxide emission $\left(\mathrm{CO}_{2} \mathrm{EM}\right): \mathrm{CO}_{2}$ emissions from electricity and heat production is the sum of three IEA categories of $\mathrm{CO}_{2}$ emissions: (1) Main Activity Producer Electricity and Heat which contains the sum of emissions from main activity producer electricity generation, combined heat and power generation and heat plants. (2) Emissions from gas flaring and local manufacturers of fuel in rural areas. Main activity producers (formerly known as public utilities) are defined as those undertakings whose primary activity is to supply the public. Data are gotten from World Bank economic indicator 2016.

The data for this study was obtained from secondary sources, particularly from CBN publications such as the CBN Statistical Bulletin, CBN Economic and Financial Review Bulletin (2015) and data from World Bank economic indicator 2016.

\subsection{Unit Root Test}

Unit root test is a test conducted to check for the stationarity of time series variables. Stationary time series variables have mean and variance constant over the period. The null hypothesis is that there is no stationarity. But if the test-statistics is greater than the critical value in absolute terms we reject the null hypothesis. Table 1 is the ADF unit root test. It shows that all the variables are stationary at first difference. That is, they are integrated of order one. The null hypothesis which is not supposed to be rejected if the critical value at $5 \%$ level was greater than the test-statistics is rejected.
According to the result, we do not reject the hypothesis that there is stationarity, hence the ADF test statistics is greater than the critical value at $5 \%$ critical value.

\subsection{Simultaneity Test}

According to the Hausman-specification test, the null hypothesis is that there is no simultaneity. If the coefficient of the residual is statistically significant we reject the null hypothesis of no simultaneity.

From Table 2 the residual (resid) coefficient is statistically significant with a probability $(0.000)<0.05$. Thus we reject the null hypothesis of no simultaneity and proceed to use 2-SLS as the most consistent and efficient estimator.

\subsection{Regression Result of Life Expectancy at Birth}

To achieve objective on- which is to know the impact of health expenditure on health outcome, we ran the 2-SLS regression as specified in chapter 3.

Table 3 is the 2-SLS regression result for health outcome. The result shows that $96 \%$ of health outcome (life expectancy at birth) is explained by the independent variable: Gross domestic product per person employed (GDPPC), FEMEDU, public health expenditure (GHE) and carbon emission $\left(\mathrm{CO}_{2} \mathrm{EM}\right)$. This is as the R-Squared is 0.9520 . It also means that $4 \%$ of the life LEB is explained by other variables outside this model. The wald Chi-square probability

Table 1: ADF unit root test result (1980-2015)

\begin{tabular}{lcl} 
Variables & $\begin{array}{c}\text { ADF test statistics } \\
\text { (first difference) }\end{array}$ & $\begin{array}{l}\text { Remarks } \\
\mathbf{( 5 \%} \text { level of significance) }\end{array}$ \\
GDPPC & -4.837 & Stationary I (1) \\
LEB & -6.861 & Stationary I (1) \\
FEMEDU & -9.328 & Stationary I (1) \\
GHE & -6.154 & Stationary I (1) \\
GFCF & -4.628 & Stationary I (1) \\
$\mathrm{CO}_{2}$ EM & -9.668 & Stationary I (1) \\
LFPR & -3.974 & Stationary I (1) \\
\hline
\end{tabular}

Source: Authors computation from STATA 11. GDPPC: Gross domestic product per capita, LEB: Life expectancy at birth, FEMEDU: Female education, GHE: Government health expenditure, GFCF: Gross fixed capital formation, $\mathrm{CO}_{2} \mathrm{EM}$ : Carbon emission, LFPR: Labor force participation rate

Table 2: Test for simultaneity

\begin{tabular}{lc} 
Variable & Coefficient \\
Residual & $4.1790(0.001)$ \\
R-square & 0.9071 \\
P-value of F-statistics & 0.0000 \\
\hline
\end{tabular}

Source: STATA output; P value in parenthesis

Table 3: 2-SLS result for impact of health expenditure on health outcome

\begin{tabular}{lc} 
Variables & Coefficients \\
Female education & $0.2612(0.044)$ \\
Gross domestic product per-capita & $0.1088(0.000)$ \\
Government health expenditure & $0.0052(0.000)$ \\
Carbon-dioxide emission & $-0.0047(0.501)$ \\
CONS & $2.0063(0.000)$ \\
N & 36 \\
PRO >Chi-square & 0.0000 \\
R-Squared & 0.9577 \\
\hline
\end{tabular}

Source: STATA output $\mathrm{P}$ values in parentheses 
is $<0.05$, shows that the model of health outcome is statistically significant. Also GDPPC met the apriori expectation with a positive coefficient and it is statistically significant with a probability $(0.000)$ $<0.05$ at $5 \%$ level of significance. This means that during the period covered by this research gross domestic product per person employed had a significant impact on life LEB in Nigeria. This is in line with the findings of Idowu (2014). The value of the coefficient is 0.1088 which means that an increase in gross domestic product of person employed by $1 \%$ will increase life expectancy by $10.8 \%$.

FEMEDU coefficient is positive which is in line with the theoretical expectations. It is statistically significant with probability value $(0.044)<0.05$ at $5 \%$ level of significance. This implies that FEMEDU had a significant impact on life expectancy in Nigeria throughout the period covered by this work. The coefficient is positive and equal to 0.2612 that is, an increase in FEMEDU by $1 \%$ will increase life expectancy by $26 \%$.

Carbon emission $\left(\mathrm{CO}_{2} \mathrm{EM}\right)$ has a negative coefficient which is in line with the theoretical expectation. However, it is insignificant in determining life expectancy at birth. This might be related to the fact that Nigeria is not as industrialized as the developed world for carbon emission to affect the lives of its citizens. However, an increase in carbon emission by one unit will reduce life expectancy by $0.47 \%$. Carbon emission's impact on life LEB for the period covered is significantly negative by this work in Nigeria.

GHE follows the apriori expectations with the positive sign of the coefficient and it is significant with the probability $(0.000)$ $<0.05$ at $5 \%$ level of significance. Thus public health expenditure impacted on life LEB in Nigeria during the period covered by this research. This is in line with the work of Anyanwu et al. (2007) and Bakare and Sanmi (2011), but against the work of Kim and Lane (2013). The coefficient value is 0.0052 that is an increase in health expenditure by $1 \%$ will increase life expectancy by $0.52 \%$. This small percentage in determining health outcome may be due low health expenditure.

\subsection{Co-integration Test Result}

Co-integration test for (life expectancy) health outcome: The variables are integrated of order one, therefore they have met the condition for Johansen co-integration test. At maximum rank zero (0), the null hypothesis is that there is no co-integration. If the trace statistics is less than the critical value, we do not reject the null hypothesis. At maximum rank three (3), the null hypothesis is that there is there is at least four co-integrating equations, if the trace statistics and max statistics is less than the critical at $5 \%$ critical value we do not reject the null hypothesis. In Table 4, the trace statistics is 10.9691 less than the critical value of 15.41 . Also the max-statistics is 9.3578 and less than the critical value at $5 \%$ level of significance which is 14.07 . Thus we do not reject the null-hypothesis that there are at least three co-integrating equations. Hence there is need for the use of vector error correction model (VECM).

\subsection{Vector Error Correction Mechanism for Health Outcome}

From Table 5 (Appendix 2), the lag one error correction factor is statistically insignificant and negative, that is -0.2038 with probability $(0.459)>0.05$; therefore, there is no long run causality from per-capita GDP, carbon emission, FEMEDU, and GHE to life LEB at lag one. But in lag two (Ce2) the error correction factor is negative and significant showing that there is long run causality in lag two. Also error committed in one period is corrected in the next period by 0.3076 . However, the probability of the lags combined for the individual variables (that is testing the lags linear hypothesis for each variable), where statistically significant with individual probability (FEMEDU $=0.0110$, GDPPC $=0.0249$, GHE $=0.0131$, $\left.\mathrm{CO}_{2} \mathrm{EM}=0.1019\right)<0.05$. This implies that there is the presence of short run causality from per-capita GDP, FEMEDU, and GHE and carbon emission to life LEB.

The Lagrangian-multiplier test showed that there is no autocorrelation with the probability value of 0.37487 above 0.05 at $5 \%$ level of significance. Also the model showed that the residuals

Table 4: Co-integration result for life expectancy (health outcome)

\begin{tabular}{|c|c|c|c|c|c|}
\hline \multicolumn{6}{|c|}{ Johansen tests for cointegration } \\
\hline \multicolumn{4}{|c|}{ Trend: constant } & \multicolumn{2}{|c|}{ Number of observation=32 } \\
\hline \multicolumn{4}{|c|}{ Sample: 1984-2015 } & \multicolumn{2}{|c|}{ Lags $=4$} \\
\hline \multicolumn{6}{|c|}{$5 \%$ maximum } \\
\hline Rank & Parms & LL & Eigenvalue & Trace statistic & Critical value \\
\hline 0 & 80 & 282.87025 & & 146.1654 & 68.52 \\
\hline 1 & 89 & 316.63102 & 0.87877 & 78.6438 & 47.21 \\
\hline 2 & 96 & 339.97221 & 0.76749 & 31.9614 & 29.68 \\
\hline 3 & 101 & 350.46838 & 0.48108 & $10.9691 *$ & 15.41 \\
\hline 4 & 104 & 355.14727 & 0.25355 & 1.6113 & 3.76 \\
\hline 5 & 105 & 355.95293 & 0.04911 & & \\
\hline \multicolumn{6}{|c|}{$5 \%$ maximum } \\
\hline Rank & Parms & LL & Eigenvalue & Maximum statistic & Critical value \\
\hline 0 & 80 & 282.87025 & & 67.5215 & 33.46 \\
\hline 1 & 89 & 316.63102 & 0.87877 & 46.6824 & 27.07 \\
\hline 3 & 96 & 339.97221 & 0.76749 & 20.9923 & 20.97 \\
\hline 3 & 101 & 350.46838 & 0.48108 & 9.3578 & 14.07 \\
\hline 4 & 104 & 355.14727 & 0.25355 & 1.6113 & 3.76 \\
\hline 5 & 105 & 355.95293 & 0.04911 & & \\
\hline
\end{tabular}

Source: Authors computation from STATA13 
are normally distributed as the Jargue-bera test has a probability value of $0.088>0.05$ at $5 \%$ level of significance.

\section{DISCUSSIONS}

The paper aimed at investigating the extent carbon dioxide emission has affected life expectancy in the Niger Delta. Availability of Data has made narrowed our findings to one explanatory variablecarbon dioxide emission. The extent of the damage will help us define the position if we are close to sustainable development or far apart. It is interesting to know that Carbon emission $\left(\mathrm{CO}_{2} \mathrm{EM}\right)$ has a negative coefficient which is in line with the theoretical expectation. What this result implies is that those who inhale this dangerous substance are prone to have health challenges and possible die young. However, it is insignificant in determining life expectancy at birth. This might be related to the fact that Nigeria is not as industrialized as the developed world for carbon emission's effect to reach such magnitude. However, an increase in carbon emission by one unit will reduce life expectancy by $0.47 \%$.

Nevertheless, there are calls for low carbon economy that will reduce gas flaring (Gul'nar et al., 2019). The other control variables exerted impact on health outcome. For example, Health expenditure has a positive and significant impact on health outcome in Nigeria with the probability $(0.000)<0.05$ at $5 \%$ level of significance. This follows the works of Anyawu et al. (2007) and Bakare and Sanmi(2011), but against the work of Kim and Lane (2013). Further, health expenditure has a negative and significant impact on economic growth in Nigeria, but can only exert long run causality to economic growth. This might be due to the fact that health expenditure is not properly channeled to the right source and as well as corruption in Nigeria. This is in line with the work of Eneji et al. (2013) who found that government total health expenditure has a negative impact on gross domestic product.

\section{CONCLUSION AND RECOMMENDATIONS}

The sustainable development of the environment is non-negotiable. People depend on the environment in which they live and business depends on people in one way or the other.

This paper has traced the complex linkages that exist between oil exploitation environmental degradation. It argues that as the exploitation of oil in the region rapidly expands, and deepens, much of the natural environment on which the local people depends is being depleted and degraded. This has created two interrelated negative pressure points for the resilience of the Niger Delta environment: It has increased the level of oil exploitation and generated more gas flaring, thereby contributing to global climate change with negative environmental hazards to Niger Delta environment.

The paper thus recommends that concerted efforts should be made to establish the right institutional framework for managing the environment. The federal, state and local governments should make sincere efforts to call the multinational oil companies to order. The MNCs should also be made to comply with the
United Nations environmental policies. The multinational oil companies have to be made to pay compensations. This could be done by strengthening the legal system. MNCs should engage in social responsibilities by investing in their environments.

\section{REFERENCES}

Abubakar, A.B. (2013), Education and sustainable national development in Nigeria: Challenges and way forward. International Letters of Social and Humanistic Sciences, 14, 65-72.

Adati, A.K. (2012), Oil exploration and spillage in the Niger delta of Nigeria. Civil and Environmental Research Journal, 2, 38-51.

Ajugwo, A.O. (2013), Negative effects of gas flaring: The Nigerian experience. Journal of Environment Pollution and Human Health, $1,6-8$.

Akpan, N. (2012), From agriculture to petroleum oil production: What has changed about Nigeria's rural development. International Journal of Developing Societies, 2(5), 97-106.

Akpokodje, J., Salau, S. (2015), Oil pollution and agricultural productivity in the Niger delta of Nigeria. Journal of Environmental Economics, 6(4), 68-75.

Al Mamun, M., Sohag, K., Mia, M.A.H., Uddin, G.S., Ozturk, I. (2014), Regional differences in the dynamic linkage between $\mathrm{CO}_{2}$ emissions, sectoral output and economic growth. Renewable and Sustainable Energy Reviews, 38, 1-11.

Alakpodia, I. (1990), Effects of Gas Flaring on the Micro-Climate and Adjacent Vegetation in Isoko Area of Bendel State. University of Ibadan, Ibadan: Unpublished MSc Thesis.

Alakpodia, I.J. (1989), The Effects of Gas Flaring on the Micro-climate and Adjacent Vegetation in Isoko Area of Bendel State. Unpublished M.Sc. Thesis, University of Ibadan.

Alakpodia, J. (2000), Soil characteristics under gas flare in Niger delta, Southern Nigeria geo studies forum. An International Journal of Environmental and Policy Issues, 1, 1-10.

Aminu, J. (1997), Nigeria and the world of oil. In: Eromosele, V.E., editor. Nigerian Petroleum Business: A Handbook. Lagos: Advance Communications.

Anifowose, B. (2008), Assessing the Impact of Oil and Gas Transportation on Nigeria's Environment. Postgraduate Research Conference. Birmingham: University of Birmingham, UK.

Anyalechi, K.C., Chijindu, H.E., Josaphat, U.J.O., Okereke, E.J. (2019), Does oil price fluctuation affect stock market returns in Nigeria? International Journal of Energy Economics and Policy, 9(1), 194-199.

Anyanwu, J.C., Erhijakpor, A.E. (2007), Health Expenditure and Health Outcome in Africa. Economic Research Working Paper Series No. 91.

Atubi, A.O., Ogbija, T.E., Ojeh, V.N. (2015), Effects of environmental degradation on human health in selected oil communities in Delta state. Journal of Environment and Earth Science, 5(9), 72-88.

Auty, R. (1997), Natural resource endowment, the state and development strategy. Journal of International Development, 9, 651-663.

Auty, R.M. (2001a), Resource Abundance and Economic Development. Oxford: Oxford University Press. p360.

Auty, R.M. (2001b), The Political Economy of Growth Collapses in Mineral Economies. Mineral and Energy Press. Proceedings of the International Mining Seminar: Global Investment, Local Challenges. p180.

Bakare, A.S., Fawehinmi, F.O. (2010), An econometric study of the contribution of oil sector to the standard of living in Nigeria. Asian Journal of Business and Management Sciences, 1(3), 1-8.

Bakare, A.S., Sanmi, O. (2011), Health care expenditure and economic growth in Nigeria: An empirical study. Journal of Emerging Trends in Economics and Management Sciences, 2(2), 83-87. 
Bassey, N. (2001), Oil and Gas in Africa: Ecological Debt Huge as the Sky. Paper Presented during the Globalization, Ecological Debt, Climate Change and Sustainability: A South South Conference, held in Benin, in November 21, Organized by Accison Ecological from Ecuador, Friends of the Earth, Benin and Friends of the Earth International.

Bekturganova, M., Satybaldin, A., Yessekina, B. (2019), Conceptual framework for the formation of low-carbon development: Kazakhstan's experience. International Journal of Energy Economics and Policy, 9(1), 48-56.

Clay, K., Wright, G. (2005), Order without law? Property rights during the California gold rush. Explorations in Economic History, 42, 155-183.

Collier, P., Hoeffler, A. (1998), On the economic causes of civil war. Oxford Economic Papers, 50, 563-573.

Congleton, R.D., Arye, L.H., Kai, A.K. (2008), Forty Years of Research on Rent Seeking: An Overview. Berlin: Springer.

Crowson, P. (1996), The European mining industry: What future? Resources Policy, 22, 99-105.

Cuaresma, J., Oberhofer, H., Raschky, P. (2011), Oil and the duration of dictatorships. Public Choice, 148(3/4), 505-530.

David, P.A., Wright, G. (1997), The genesis of American resource abundance. Industrial and Corporate Change, 6, 203-245.

Dernback, J.C. (2002), Stumbling Toward Sustainability. Washington, DC: Environmental Law Institute. p608.

Dosunmu, A., Amadi, B.C. (1996), Evaluation of the Effect of Gas Flares on the Environment; Proceedings of the Twentieth Annual International Conference. The Society of Petroleum Engineers, Nigeria Council. p45-49.

Efe, S.I. (2003), Effects of gas flaring on temperature and adjacent vegetation in Niger Delta environment. International Journal of Environmental Issues, 1(1), 91-101.

Ejuwa, G.A. (2005), Saving the Niger Delta from Oil Pollution. Available from: http://www.vanguardngr.com/articles/2002/viewpoints/ vp207042005.html-34k.

Eneji, M.A., Vonke, D.J., Bisong, J.O. (2013), Health care expenditure, health status and national productivity in Nigeria. Journal of Economics and International Finance, 5(7), 258-272.

Gogoi, N., Baruoh, K.K. (2002), Effects of Natural Gas Flare on Growth, Flowering and Yield of Rice. Available from: http://www.envfor.nic. in/paryaabs/v19n12/plant.html.

Gul'nar, O.K., Sopilko, N.Y., Illeritsky, N.I. (2019), Republic of Turkey gas complex development: Problems and prospects. International Journal of Energy Economics and Policy, 9(1), 346-355.

Isichei, O., Stanford, A. (1996), Implications of oil exploration on agricultural development in delta state, Nigeria. International Journal of Humanities and Social Science Invention, 2(4), 59-63. Available from: http://www.ijhssi.org. [Last accessed on $2013 \mathrm{Apr}$ 04].

Idowu, D.O. (2014), The impact of health on economic growth in Nigeria. Journal of Economic and Sustainable Development, 5(19), 38-52.

Kadafa, A.A. (2012), Environmental impacts of oil exploration and exploitation in the Niger Delta of Nigeria. Global Journal of Science Frontier Research Environment and Earth Sciences, 12(3), 19-28.

Karl, T. (1997), The Paradox of Plenty: Oil Booms and Petro-states. Berkeley: University of California Press.

Kim, T.K., Lane, S.R. (2013), Government health expenditure and public health outcomes: A comparative study among 17 countries and implications for US health care reform. American International Journal of Contemporary Research, 3(9), 8-13.

Kreuger, A. (1974), The political economy of the rent seeking society. American Economic Review, 64, 291-303.

Lasbrey, A., Tobechi, A., Yuni, D., Chukwu, B. (2018), Nigeria's economic growth and the sisyphus odyssey: A theoretical retrospect. Jurnal Perspektif Pembiayaan dan Pembangunan Daerah, 6(3), 291-302.

Mahdavy, H. (1970), The patterns and problems of economic development in Rentier states: The case of Iran. In: Cook, M., editor. Studies in
Economic History of the Middle East. London: Oxford University Press. p428-467.

Manasseh, C.O., Abada, C., Ogbuabor, J.E., Okoro, E.U., Ebeke, A., Ozuzu, K.C. (2019), Oil price fluctuation, oil revenue and well-being in Nigeria. International Journal of Energy Economics and Policy, 9(1), 346-355.

Marope, P.T.M., Chakroun, B., Holmes, K.P. (2015), Unleashing the Potential: Transforming Technical and Vocational Education and Training (PDF). United Nations: UNESCO Publishing. p9, 23, 25-26.

Matthew, A.O., Ede, C., Osabohien, R., Ejemeyovwi, J., Fasina, F.F., Akinpelumi, D. (2018), Electricity consumption and human capital development: Exploring the implications for economic growth in Nigeria. International Journal of Energy Economics and Policy, $8(6), 1-8$.

Matthew, O., Osabohien, R., Fagbeminiyi, F., Fasina, A. (2018b), Greenhouse gas emissions and health outcomes in Nigeria: Empirical insight from auto-regressive distribution lag technique. International Journal of Energy Economics and Policy, 8(3), 43-50.

McGuirk, E. (2013), The illusory leader: Natural resources, taxation and accountability. Public Choice, 154, 285-313.

Morrison, K. (2007), Natural resources, aid, and democratization: A bestcase scenario. Public Choice, 131(3/4), 365-386.

NNPC. (2013), NNPC Annual Statistical Bulletin: Retrieved. Available from: http://www.nnpcgroup.com/PublicRelations/ OilandGasStatistics/AnnualStatisticsBuletin.aspx. [Last accessed on 2018 Dec 10].

Nugraha, A.T., Osman, N.H. (2019), $\mathrm{C}_{\mathrm{O} 2}$ emissions, economic growth, energy consumption, and household expenditure for Indonesia: Evidence from cointegration and vector error correction model. International Journal of Energy Economics and Policy, 9(1), 291-298.

Nwilo, P.C., Badejo, O.T. (2001), Impacts of Oil spills along the Nigerian Coast. The Association for Environmental Health and Science. Available from: http://www.aehsmag.com/issues/2001/october/ impacts.htm. [Last accessed on 2007 Nov].

Nwilo, P.C., Badejo, O.T. (2008), Oil Dispersion and Trajectories on Nigerian Open Sea. The Conference Proceedings of the International Conference on the Nigeria State, Oil Industry and the Niger Delta p164-192.

Obioma, B.K. (1985), An Enquiry into Lack of Investment in Agriculture by the Oil Communities: The Case of Ogba-Egbema and Oguta Communities, Seminar on energy, University of Port-Harcourt, Port-Harcourt.

Ogidiolu, A. (2003), Effects of gas flaring on soil and vegetation characteristics in oil producing region of Niger Delta, Nigeria. International Journal of Ecology and Environmental Dynamics, 1, 47-53.

Okonkwo, C.N.P., Kumar, L., Taylor, S. (2015), The Niger Delta wetland ecosystem: What threatens it and why should we protect it? African Journal of Environmental Science and Technology, 9(5), 451-463.

Olaolou, A.L. (2008), MNCs and Sustainable Environmental Development: An Assessment of the Niger Delta and Texas. International Conference on the Nigerian State, Oil Industry and the Niger Delta: Conference Proceedings.

Olisemauche, O.O., Avwerosuoghene, O.P. (2015), The effect of gas flaring on agricultural production of Okpai, Ndukwa East local government area, Delta state, Nigeria. Standard Scientific Research and Essays, 3(9), 266-272.

Onuoha, F.C. (2007), Poverty, pipeline vandalization/explosion and human security. Integrating disaster management into poverty reduction in Nigeria. African Security Review, 16(2), 94-108.

Onuoha, F.C. (2008), Oil Exploitation, Environmental Degradation and Climate Change: Assessing the Vulnerability of the Niger Delta Environment to Natural Disaster. African Centre for Strategic Research and Studies. Port Harcourt: Harey Publications Company. 
Omuta, (1985), Implications of oil exploration on agricultural development in delta state, Nigeria. International Journal of Humanities and Social Science Invention, 2(4), 59-63. Available from: http://www.ijhssi. org. [Last accessed on 2013 Apr 04].

Osabohien, R., Oluwatoyin, M., Aderounmu, B., Olawande, T. (2019), Greenhouse gas emissions and crop production in West Africa: Examining the mitigating potential of social protection. International Journal of Energy Economics and Policy, 9(1), 57-66.

Osuagwu, E.S., Olaifa, E. (2018), Effects of oil spills on fish production in the Niger Delta. PLoS One, 13(10), e0205114.

Ozturk, I., Acaravci, A. (2013), The long-run and causal analysis of energy, growth, openness and financial development on carbon emissions in Turkey. Energy Economics, 36, 262-267.

Patrick, O. (2004), Essentials of Comparative Politics. New York, London: Norton. p147.

Plessl, C., Otachi, E.O., Körner, W., Avenant-Oldewage, A., Jirsa, F. (2017), Fish as bioindicators for trace element pollution from two contrasting lakes in the Eastern rift valley, Kenya: Spatial and temporal aspects. Environmental Science and Pollution Research, 24, 19767-19776.

Ross, M. (2012), The Oil Curse: How Petroleum Wealth Shapes the Development of Nations. Princeton: Princeton University Press.

Sachs, J., Warner, A. (2001), The curse of natural resources. European Economic Review, 45(4), 827-838.

Sachs, J.D., Andrew, W. (1997b), Sources of slow growth in African economies. Journal of African Economies, 6, 335-376.

Sachs, J.D., Warner, A.M. (1995), Natural Resource Abundance and Economic Growth, NBER Working Paper 5398. National Bureau of Economic Research, 49.

Sachs, J.D., Warner, A.M. (1995b), Natural Resource Abundance and Economic Growth. Development Discussion Paper No. 517a. Harvard Institute for International Development.

Tullock, G. (1967), The welfare costs of tariffs, monopolies, and theft. Western Economic Journal, 5, 224-232.

Ugoh, S.C. (2008), Oil politics and crisis of development in the Niger Delta. Journal of Sustainable Development in Africa, 10(2), 91-115.

Ugwaren, I. (2008), Groups Petition National Assembly on 2008 Gas Faring Deadline. Lagos: This Day.

Ukegbu, D., Okeke, A.O. (1987), Flaring of Associated Gas in Oil and Gas Industry: Impact on Growth, Productivity and Yield of Selected Farm Crops in Petroleum Industry and the Nigeria Environment, Proceedings of 1987 Seminar, NNPC, Lagos.

UNESCO. (2015), Rethinking Education: Towards a Global Common Good? Paris: UNESCO. pp9-10, 33.

Uzoma, A.C., Mgbemena, O.O. (2015), Evaluation of some oil companies in the Niger Delta region of Nigeria: An environmental impact approach. International Journal of Environment and Pollution Research, 3(2), 13-31.

Wright, G. (1990), The origins of American industrial success, 1879-1940. American Economic Review, 80, 651-668. 


\section{APPENDIX}

Appendix 1: Data for regression model

\begin{tabular}{|c|c|c|c|c|c|c|c|}
\hline Year & LEB & FEMEDU & GDPPC & GHE & GFCF & $\mathrm{CO}_{2} \mathrm{EM}$ & LFPR \\
\hline 1980 & 45 & 43.493 & 1118.824 & 70000 & 36.23 & 13.7 & 55.64 \\
\hline 1981 & 46 & 43.7 & 1080.717 & 80000 & 35.22 & 14.9 & 55.43 \\
\hline 1982 & 46 & 43.588 & 1312.406 & 100000 & 31.95 & 15 & 55.81 \\
\hline 1983 & 46 & 42.977 & 1603.407 & 80000 & 23 & 7 & 56.63 \\
\hline 1984 & 46 & 43.035 & 1464.005 & 100000 & 14.22 & 5.6 & 56.56 \\
\hline 1985 & 46 & 44.02 & 1398.523 & 130000 & 11.96 & 7.6 & 56.57 \\
\hline 1986 & 46 & 44.289 & 1476.526 & 130000 & 15.15 & 8.6 & 56.45 \\
\hline 1987 & 46 & 44.385 & 1312.593 & 40000 & 13.6 & 11.3 & 56.71 \\
\hline 1988 & 46 & 42.413 & 1141.06 & 420000 & 11.87 & 11.2 & 56.74 \\
\hline 1989 & 46 & 44.994 & 1195.211 & 580000 & 14.25 & 18.73 & 56.76 \\
\hline 1990 & 46 & 43.194 & 1239.649 & 500000 & 40.12 & 19.61 & 56.964 \\
\hline 1991 & 46 & 43.805 & 1362.265 & 620000 & 39.97 & 19.8 & 56.939 \\
\hline 1992 & 46 & 44.118 & 1319.782 & 150000 & 38.97 & 18.3 & 56.898 \\
\hline 1993 & 46 & 43.727 & 1292.471 & 3870000 & 38.77 & 17.9 & 56.845 \\
\hline 1994 & 46 & 44.065 & 1286.834 & 2090000 & 44.97 & 16.9 & 56.78 \\
\hline 1995 & 46 & 44.543 & 1266.518 & 3320000 & 40.4 & 15.27 & 56.704 \\
\hline 1996 & 46 & 45.29 & 1231.511 & 3020000 & 29.82 & 26.21 & 56.601 \\
\hline 1997 & 46 & 45.11 & 1261.141 & 3890000 & 35.22 & 26.56 & 56.478 \\
\hline 1998 & 46 & 45 & 1264.512 & 4740000 & 38.33 & 28.51 & 56.333 \\
\hline 1999 & 46 & 43.83 & 1266.779 & 16640000 & 36.39 & 26.92 & 56.164 \\
\hline 2000 & 47 & 43.93 & 1241.287 & 15220000 & 35.33 & 16.97 & 55.968 \\
\hline 2001 & 47 & 44.41 & 1274.931 & 24520000 & 41.34 & 14.1 & 55.732 \\
\hline 2002 & 47 & 44.38 & 1297.931 & 40620000 & 6.33 & 13.9 & 55.458 \\
\hline 2003 & 48 & 44.46 & 1313.375 & 33270000 & 7.94 & 13.93 & 55.14 \\
\hline 2004 & 48 & 44.884 & 1412.904 & 34200000 & 12.99 & 19.13 & 54.774 \\
\hline 2005 & 50 & 44.35 & 1841.611 & 55660000 & 44.44 & 17.51 & 54.911 \\
\hline 2006 & 50 & 45.98 & 1856.225 & 62250000 & 39.8 & 21.87 & 55.054 \\
\hline 2007 & 50 & 46.13 & 1956.689 & 81910000 & 63.43 & 23.4 & 55.203 \\
\hline 2008 & 50 & 46.34 & 2035.831 & 98220000 & 89.9 & 21.49 & 55.353 \\
\hline 2009 & 51 & 46.66 & 2106.743 & 90200000 & 89.24 & 23.54 & 55.502 \\
\hline 2010 & 51 & 47.3 & 2193.445 & 99100000 & 120.27 & 21.96 & 55.646 \\
\hline 2011 & 52 & 48.3698 & 2302.829 & 231800000 & 142.32 & 29.16 & 55.789 \\
\hline 2012 & 52 & 48.36 & 2351.281 & 197900000 & 126.94 & 29 & 55.928 \\
\hline 2013 & 52 & 48.7 & 2386.758 & 179990000 & 101.7 & 28.25 & 56.059 \\
\hline 2014 & 52 & 49.21 & 2448.9 & 1959800000 & 17.24 & 29 & 56.181 \\
\hline 2015 & 53 & 49.23 & 2535.068 & 2577720000 & 22.7 & 28 & 56.306 \\
\hline
\end{tabular}

Source: Authors compilation from the World Bank Development Indicator and Central Bank of Nigeria statistical bulletin. LEB: Life expectancy at birth, FEMEDU: Female education, GHE: Government health expenditure, GFCF: Gross fixed capital formation, $\mathrm{CO}_{2} \mathrm{EM}$ : Carbon emission, LFPR: Labor force participation rate

\section{Appendix 2}

Table 5: VECM (life expectancy at birth)

\begin{tabular}{|c|c|c|c|c|c|c|}
\hline \multicolumn{7}{|l|}{ Vector error-correction model } \\
\hline \multirow[t]{2}{*}{ Sample: 1984-2015 } & & & \multicolumn{4}{|c|}{ No. of observaion $=32$} \\
\hline & & & \multicolumn{4}{|c|}{$\mathrm{AIC}=-\mathbf{1 5 . 5 9 1 7 7}$} \\
\hline Log likelihood $=\mathbf{3 5 0 . 4 6 8 4}$ & & & \multicolumn{4}{|c|}{ HQIC $=-14.05831$} \\
\hline \multicolumn{3}{|l|}{ Det $($ Sigma_ml $)=2.11 \mathrm{e}-16$} & \multicolumn{4}{|c|}{ SBIC $=-10.96554$} \\
\hline Equation & Parms & RMSE & R-square & Chi-square & P $>$ Chi-squart & \\
\hline D_logleb & 19 & 0.007228 & 0.8166 & 53.44141 & 0.0000 & \\
\hline D_logfemedu & 19 & 0.017528 & 0.6271 & 20.17808 & 0.3839 & \\
\hline $\mathrm{D}^{-} \operatorname{loggdppc}$ & 19 & 0.048938 & 0.7944 & 46.37992 & 0.0004 & \\
\hline D logghe & 19 & 0.559956 & 0.8288 & 58.10738 & 0.0000 & \\
\hline \multirow[t]{2}{*}{ D_logco2em } & 19 & 0.198505 & 0.6159 & 19.23975 & 0.4416 & \\
\hline & Coefficient & $\begin{array}{l}\text { Standard } \\
\text { error }\end{array}$ & $\mathrm{z}$ & $\mathrm{P}>|\mathrm{z}|$ & (95\% confid & ce interval) \\
\hline \multicolumn{7}{|l|}{ D_logleb $_{\text {ce } 1}$} \\
\hline $\begin{array}{l}\text { L1. } \\
\text { ce2 }\end{array}$ & -0.2038237 & 0.2752003 & -0.74 & 0.459 & -0.7432064 & 0.3355591 \\
\hline L1. & -0.3075809 & 0.1272478 & -2.42 & 0.016 & -0.5569819 & -0.0581799 \\
\hline
\end{tabular}




\section{Appendix 2}

\section{Table 5: (Continued)}

$$
\text { -ce3 }
$$

L1.

logleb

LD.

L2D.

L3D.

logfemedu
LD.
L2D.
L3D.

$\operatorname{loggdppc}$

LD.

L2D.

L3D.

logghe
LD.
L2D.
L3D.

$\log \mathrm{co} 2 \mathrm{em}$
LD.
L2D.

L3D.

(1) [D_logleb] LD.logfemedu $=0$

(2) [D_logleb] L2D.

logfemedu $=0$

(3) [D_logleb] L3D.

logfemedu $=0$

Chi-square (3) $=11.14$

Prob $>$ Chi-square $=0.0110$

Test ([D_logleb]: LD.logghe

L2D.logghe L3D.logghe)

(1) [D_logleb] LD.logghe $=0$

(2) [D_logleb] L2D.logghe $=0$

(3) $[$ D_logleb] L3D.logghe $=0$

Chi-square (3) =

10.76Prob $>$ Chi-square $=0.0131$

Test ([D_logleb]: LD.loggdppc

L2D.loggdppc L3

D.loggdppc)

(1) [D_logleb] LD.loggdppc $=0$

(2) [D_logleb] L2D. $\operatorname{loggdppc}=0$

(3) $\left[\mathrm{D} \_\right.$logleb] L3D.loggdppc $=0$

Chi-square $(3)=9.36$

Prob $>$ Chi-square $=0.0249$

Test ([D_logleb]: LD.logco2em L2D.logco2em L3D.logco2em)

(1) [D_logleb] LD.logco2em=0

(2) [D_logleb] L2D. $\log c 02 \mathrm{em}=0$

(3) [D_logleb] L3D. logco2em=0

Chi-square $(3)=11.16$

Prob $>$ Chi-square $=0.0109$

Veclmar

Lagrange-multiplier test

Lag

1
$0.0659845 \quad 0.0546604$

1.21

0.227

$-0.0411479$

0.1731168

$-0.6416134$

$-0.2051603$

0.3047146

0.3096444

$-0.0665271$

0.2513828

$-2.11$

$-0.66$

$-0.26$

0.035

0.508

0.791

$-0.235931$

$-0.6906583$

0.1581397

$-1.49$

$-3.19$

$-0.3018806$

0.1368816

$-2.21$

0.136

0.001

0.027

$-0.0025125$

0.0388357

0.0471324

0.0400341

$-0.082772$

0.0380755

$-0.05$

0.97

0.957

0.332

0.030

$-0.006208$

0.0028033

0.0030343

0.027

0.002

$-0.0034578$

0.002353

$-2.21$

$-3.17$

0.142

0.0117023

$-0.015577$

$-0.0080695$

$-0.0036827$

0.0011539

0.0336546

0.0116989

0.0131893

0.0157316

0.0133307

2.88

1.19

0.004

0.233

0.128

0.0107253

$-0.0101189$

0.056584

$-1.52$

$-0.0464161$

0.074017

$-0.0335976$

0.0898653

0.1173011

$-0.0081455$ 
Appendix 2

Table 5: (Continued)

$\begin{array}{lccc}2 & 26.6250 & 25 & 0.37487 \\ \begin{array}{l}\mathrm{H}_{0}: \text { No autocorrelation at lag } \\ \text { order }\end{array} & & & \\ \text { Jarque-Bera test } & \text { Chi-square } & \text { df } & \text { Prob }>\text { Chi-square } \\ \text { Equation } & 5.377 & 2 & 0.06797 \\ \text { D_logleb } & 0.224 & 2 & 0.89425 \\ \text { D_logfemedu } & 1.819 & 2 & 0.40279 \\ \text { D_loggdppc } & 1.369 & 2 & 0.50434 \\ \text { D_logghe } & 7.635 & 2 & 0.02198 \\ \text { D_logco2em } & 16.423 & 10 & 0.08813 \\ \text { ALL } & & \end{array}$

VECM: Vector error correction model 